\title{
Has Falling Crime Invited Gentrification?
}

by

\author{
Ingrid Gould Ellen \\ New York University
}

Keren Mertens Horn

University of Massachusetts Boston

\author{
Davin Reed \\ New York University
}

\begin{abstract}
CES 17-27 March, 2017
The research program of the Center for Economic Studies (CES) produces a wide range of economic analyses to improve the statistical programs of the U.S. Census Bureau. Many of these analyses take the form of CES research papers. The papers have not undergone the review accorded Census Bureau publications and no endorsement should be inferred. Any opinions and conclusions expressed herein are those of the author(s) and do not necessarily represent the views of the U.S. Census Bureau. All results have been reviewed to ensure that no confidential information is disclosed. Republication in whole or part must be cleared with the authors.

To obtain information about the series, see www.census.gov/ces or contact J. David Brown, Editor, Discussion Papers, U.S. Census Bureau, Center for Economic Studies 5K034A, 4600 Silver Hill Road, Washington, DC 20233, CES.Working.Papers@census.gov. To subscribe to the series, please click here.
\end{abstract}




\begin{abstract}
Over the past two decades, crime has fallen dramatically in cities in the United States. We explore whether, in the face of falling central city crime rates, households with more resources and options were more likely to move into central cities overall and more particularly into low income and/or majority minority central city neighborhoods. We use confidential, geocoded versions of the 1990 and 2000 Decennial Census and the 2010, 2011, and 2012 American Community Survey to track moves to different neighborhoods in 244 Core Based Statistical Areas (CBSAs) and their largest central cities. Our dataset includes over four million household moves across the three time periods. We focus on three household types typically considered gentrifiers: high-income, collegeeducated, and white households. We find that declines in city crime are associated with increases in the probability that high income and college-educated households choose to move into central city neighborhoods, including low-income and majority minority central city neighborhoods. Moreover, we find little evidence that households with lower incomes and without college degrees are more likely to move to cities when violent crime falls. These results hold during the 1990s as well as the 2000s and for the 100 largest metropolitan areas, where crime declines were greatest. There is weaker evidence that white households are disproportionately drawn to cities as crime falls in the 100 largest metropolitan areas from 2000 to 2010.
\end{abstract}

Keyword: crime, gentrification, neighborhood choice

JEL Classification: R23, R21, R11

\footnotetext{
* Any opinions and conclusions expressed herein are those of the authors and do not necessarily represent the views of the U.S. Census Bureau. All results have been reviewed to ensure that no confidential information is disclosed.The research in this paper was conducted while the authors were Special Sworn Status researchers of the U.S. Census Bureau at the New York Census Research Data Center.
} 


\section{Introduction}

Over the past two decades, crime has fallen dramatically in the United States. From the peak in 1991 to 2012, the national violent crime rate fell by 49 percent. Crime rates fell even more significantly in central cities. ${ }^{1}$ This same period saw growing proportions of high-income, college-educated, and white households opting to live in cities and in low-income and majority minority (nonwhite) neighborhoods within those cities. In this analysis, we explore whether these phenomena are related. We use restricted Decennial Census and American Community Survey data combined with city-level data on violent crime and homicides to explore whether the dramatic decrease in crime that occurred in U.S. cities over the past two decades spurred gentrification. Specifically, we ask whether falling city crime made high-income, collegeeducated, and white households more likely to move into urban neighborhoods and into lowincome and nonwhite urban neighborhoods in particular.

A number of prior studies have examined the extent to which crime shapes residential location decisions. ${ }^{2}$ Researchers have mostly explored whether increases in crime drive households out of neighborhoods or cities and/or discourage people from entering specific neighborhoods or cities. The results typically show that increases in crime rates are followed by population losses (Frey, 1979; Morenoff and Sampson, 1997; Nechyba and Strauss, 1997; Cullen and Levitt, 1999; Bayoh, Irwin and Haab, 2006). In one of the most cited works in this literature, Cullen and Levitt (1999) find that a 10 percent rise in central city crime corresponds to a 1 percent decline in central city population.

\footnotetext{
${ }^{1}$ During our study period from 1988 to 2008, crime fell 28 percent nationally and 34 percent in our sample of central cities of the 244 biggest CBSAs.

${ }^{2}$ For a complete review of the literature on crime and neighborhood change see Kirk and Laub (2010). For the purpose of this paper, we focus on a subset of studies that examine the relationship between crime and population changes.
} 
There is a smaller literature exploring whether the effects of rising and declining crime are symmetric - and whether falling crime can attract households to the central city. Ellen and O’Regan (2010) examine this question and find little evidence that reductions in central city crime during the 1990s attracted households to move into cities during the same time period. They do, however, find support for a retention effect: lower levels of city crime are associated with lower levels of exodus to the suburbs.

We examine a related question: Has falling violent crime changed the mix of households choosing central city neighborhoods, and low-income and nonwhite central city neighborhoods in particular? To test this, we use micro data on household moves from 1990 to 2012 and control for a rich set of household and central city characteristics as well as metropolitan area and year fixed effects. We find that reductions in central city violent crime increase the likelihood that high-income and college-educated households will choose a home in the central city over one in the suburbs. By contrast, we see little evidence that either lower-income households or households where the head of household lacks a college degree are more likely to choose central city neighborhoods when violent crime in the city falls. We find some evidence that crime reductions disproportionately attract white households, though this result is only robust for a subsample of the 100 largest MSAs from 2000 to 2010.

Importantly, when they move to central cities, high-income households are not simply opting for high-income and majority white neighborhoods. When violent crime and homicide rates fall, we find that high-income households are also more likely to choose both low-income and nonwhite central city neighborhoods as compared to suburban neighborhoods. We see no evidence that low-income households are more likely to move to low-income or non-white central city neighborhoods when violent crime rates fall. 
We see similar results for college-educated households: reductions in violent crime are associated with more college-educated households opting for both majority minority and majority white neighborhoods over suburban locations; and we see no association for those without college degrees. The evidence is somewhat weaker, but we also find that the choices of college-educated households to move into low-income city neighborhoods are more sensitive to reductions in homicides than the choices of households without college degrees.

Our finding that the residential choices of high-income and college-educated households respond more to falling violent crime in cities than their counterparts is robust to a number of specifications. The patterns hold in our full sample of 244 CBSAs from 1990 to 2010; a sample of the 100 largest CBSAs from 1990 to 2010, where crime declines were greatest; and a sample restricted to the 100 largest CBSAs from 2000 to 2010, when gentrification trends were strongest. They are robust to using the double selection method of Belloni, Chernozhukov, and Hansen (2014), a data-driven method of finding and controlling for trends in observable characteristics. The homicide results are especially robust, which is reassuring given both the salience of homicides and the heightened accuracy in their reporting.

Overall, our analyses provide new empirical evidence that falling crime has contributed to an increase in the overall likelihood that high-income and college-educated households choose central city neighborhoods as well as low-income and nonwhite central city neighborhoods in particular. Moreover, we find strong effects for high-income and college-educated households and no effects for low-income households and those without college degrees. Our results are consistent with a simple spatial model wherein a large reduction in a central city disamenity like violent crime increases the desirability of scarce land, and results in more high-income households outbidding low-income households for available homes (Brueckner et al. 1999). 
Greater shifts in the locational patterns of college-educated households could result if such households have access to more information about crime declines or if violent crime disproportionately reduces the enjoyment of the central city consumption amenities these households prefer.

Our paper proceeds as follows. We begin by describing trends in both central city crime rates and residential choices of high-income, college-educated, and white households between 1990 and 2010. We then present our theoretical and empirical approach to identifying whether falling crime induces these households to choose to move into cities and into lower-income and majority nonwhite city neighborhoods in particular. We continue by describing our data and sample. We then present our results and conclusions.

\section{Background and Theoretical Framework}

We ask two distinct research questions. First, do reductions in city violent crime differentially attract high-income, college-educated, and white households to central city neighborhoods? Second, do reductions in city violent crime differentially attract high-income, college-educated, and white households into central city neighborhoods they may not have previously considered, specifically, lower-income and nonwhite neighborhoods?

In addressing these questions, our study builds on a large and growing body of literature examining what drives urban resurgence. As far back as 1981, Kern argued that renewed interest in central city living was in part driven by a growth in a segment of the population that has a strong preference for central city goods and cultural amenities, particularly young, unmarried adults and childless couples. He found support for this argument in data from New York City in the 1970 s. 
Many theories have since been offered to explain urban resurgence, such as an aging housing stock that is ripe for renovation (Brueckner and Rosenthal, 2009), increasing importance of knowledge in the economy leading to a growth in employment in central cities (Glaeser and Gottlieb, 2006; Baum-Snow and Hartley, 2015; Couture and Handbury, 2016), increasing preferences for urban amenities (Glaeser, Kolko and Saiz, 2001; Glaeser and Gottlieb, 2006; Couture and Handbury, 2016; Baum-Snow and Hartley, 2015), declining leisure time among higher income workers (Edlund et al., 2015), and lastly reductions in crime (Ellen and O'Regan, 2010; Glaeser and Gottlieb, 2006). ${ }^{3}$ Our analysis centers on this last hypothesis. We focus on households who are making a residential move and then examine whether they are more likely to choose a central city location within the metropolitan area, controlling for a series of household, city, and CBSA characteristics.

We also draw on the large literature examining the causes of gentrification defined more specifically as moves by higher-status households into lower-status neighborhoods. This literature explores both the types of households most likely to choose lower-income or minority central city neighborhoods, as well as the metropolitan area and city conditions that lead to an increased prevalence of gentrification. Consistent with the evidence on urban resurgence, researchers find that higher-income households who are young, white, college-educated, and childless are those most likely to move into low-income neighborhoods (Ellen, Horn and O’Regan, 2013; Freeman and Braconi, 2004; Freeman, 2005; McKinnish, Walsh and White, 2010). Ellen, Horn and O’Regan (2013) find that higher-income households are more likely to choose lower-income neighborhoods in cities with rapidly appreciating housing values, as affordability pressures drive them to consider a broader set of neighborhoods. We build on this

\footnotetext{
${ }^{3}$ In a related literature Lee and Lin (2013) emphasize the importance of natural amenities in shielding high-income neighborhoods from change.
} 
literature and examine the role of improved amenities, specifically declining violent crime, in leading gentrifier households to consider moves into lower-income and largely minority neighborhoods.

To motivate our analysis of residential choices, we rely on a simple monocentric model with urban amenities, drawing on the theoretical framework presented in Brueckner et al. (1999), O’Sullivan (2005) and Couture and Handbury (2016). We consider each metropolitan area as containing two areas, the central city and the suburbs. In the initial period, crime is high in the central city and low in the suburbs, reflecting a low amenity value in the central city and a high amenity value in the suburbs. We then consider two different sets of households, gentrifier and non-gentrifier households. Each household is maximizing its utility, which is a function of amenities, commute time and housing consumption.

We first consider households separately along the dimension of income. We assume that higher-income households have a greater willingness to pay for urban amenities. In the initial time period, amenities are higher in the suburbs, as crime rates are high in the central city, and thus the amenity distribution pushes higher-income households towards the suburbs. In the second time period, after crime rates in the central city decline, amenities improve in the central city relative to the suburbs. This increases the willingness to pay of higher-income households for an urban residence, thus pulling higher-income households back towards the central city. Work by Rosenthal and Ross (2010) supports this theory, as they observe that services targeted towards higher-income households (such as high-end restaurants) are less likely to operate in areas with high levels of violent crime than are those targeting a lower-income clientele, suggesting those restaurants understand higher-income households' greater sensitivity to violent crime. 
At the same time, low-income households, or at least poor households, may be less sensitive to crime because their financial constraints force them to sacrifice neighborhood quality and safety to obtain a decent housing unit. Further, there is some evidence that poor families, who typically have more experience living in unsafe neighborhoods, have more confidence that they can manage in rough neighborhoods, in part because they know the safe blocks to live on within them (Rosenblatt and DeLuca, 2012).

As for differences between college-educated and non-college-educated households, college-educated households may have better information about changes in violent crime. College-educated households are more likely, for example, to read the newspaper ${ }^{4}$ and therefore may have a more accurate understanding of the changing patterns of violent crime. If so, their residential decisions will be more responsive to changes in crime. ${ }^{5}$ Additionally, declines in crime make it easier for households to enjoy many urban amenities, and if college-educated households have stronger preferences for those amenities (such as restaurants, parks and bicycle lanes), then reductions in crime make it more likely that they would outbid their non-collegeeducated counterparts for housing in the central city.

Finally, white and non-white households may exhibit differential sensitivities to crime, due to the constraints that non-white households face in the housing market. Minority households may simply not have the same ability as white households to avoid higher-crime areas. Further, white households may more strongly associate urban areas with unsafe environments, as some research suggests that whites more strongly associate racially mixed areas

\footnotetext{
${ }^{4}$ A Pew Research Center study finds that 67 percent of college graduates regularly read the newspaper, in comparison to 57 and 53 percent of those with some college education and those with a high school degree or less, respectively (Rainie et al., 2012).

${ }^{5}$ Kurlat and Stroebel's (2015) recent work on real estate brokers provides evidence that increased information on housing markets can help real estate brokers choose properties that are more likely to appreciate in the future.
} 
with crime (Krysan, 2002). Thus it is possible that well-publicized reductions in crime would do more to shift the residential decisions of white households.

\section{Data, Measures, and Sample}

To observe household residential choices, we rely on confidential, geocoded versions of the 1990 and 2000 Decennial Census and the 2010, 2011, and 2012 American Community Survey. Through the restricted access version of the surveys we can observe a rich set of these household's characteristics, including whether they have moved in the past year, and their census tract of residence. This level of geographic detail on individual household location is far greater than that provided in public use versions of these datasets, which only identify household location at the level of the Public Use Microdata Area (PUMA), a geographic area of approximately 100,000 people, a size too large to represent a neighborhood. We focus on the set of metropolitan areas that had a population greater than 100,000 in 1990, which includes 244 Core Based Statistical Areas (CBSAs). We identify central cities as the largest principal city within the CBSA. For example, in the New York CBSA, only the five boroughs of New York City are identified as the central city, and the remainder of the metropolitan area is considered outside of the central city, providing a loose approximation of the surrounding suburbs. We create consistent geographic boundaries over time by cross-walking CBSAs and tracts to 2010 boundaries using the Longitudinal Tract Data Base. ${ }^{6}$

Table 1 shows trends in the characteristics of these central cities over time for our sample of 244 cities. We see that these cities are growing during this time period, experiencing significant increases in the share of minority households, the share of foreign born households, poor households, and college-educated households living in central cities. Across the board then,

${ }^{6}$ http://www.s4.brown.edu/us2010/Researcher/Bridging.htm 
cities are not seeing increases in the proportion of white households or a reduction in poverty rates. $^{7}$

They are seeing reductions in crime, however. We match each CBSA-year to the per capita violent crime and homicide rates of the largest principal city of that CBSA (this principal city corresponds to our definition of central city). Violent crime and homicides are from the FBI Uniform Crime Reports 1988, 1998, and 2008, which represent one year lags from when we observe household moves (in 1989, 1999, and 2009). Trends and results are robust to using two or three year lags or an average of the three years before the move. Table 2 shows the trends in violent crime and homicides for our full sample. We see large and consistent declines in crime during our study period.

It is worth underscoring that our timing does not perfectly align with breaks in the national crime trend. Nationally, violent crime peaked in 1991, declined rapidly through 1999, and then declined more slowly, though steadily, through 2013. Because we measure our decadal crime changes from 1988 to 1998 and from 1998 to 2008 (in order to fit the timing of our moves data), our declines are not as dramatic as the decline from the peak in 1991 through the rest of the 1990s. Nevertheless, we see significant declines in violent crime, which persist throughout the full time period. As shown in Table 3, we observe wide differences across CBSAs in the extent of these declines in crime, with more than a quarter of cities in our sample actually experiencing increases in violent crime between 1988 and 2008. Thus, there is ample variation to estimate our models.

For our sample of households, we limit our analysis to those that have moved in the past year. We define three household types to capture the households who are typically considered 'gentrifiers': high-income households (household income above CBSA median household

\footnotetext{
${ }^{7}$ The growth in percentage minority in cities tracks the growth in share minority nationwide.
} 
income), college-educated households (head of household completed a college degree or more), and white households (head of household identifies as non-Hispanic white) ${ }^{8}$ Overall we observe approximately 4 million movers over all three periods: $39 \%$ of mover households are highincome, $28 \%$ are college-educated, and $69 \%$ are white.

Table 4 describes sample characteristics for our key household types. We see that highincome households in our sample are more likely to be married and have children than either college-educated households or white households; they also represent an older set of households than these other two groups.

When considering entry into low-income neighborhoods, we classify neighborhoods along three major dimensions: central city versus suburban (as described above), high-income versus low-income (tract median household income above/below CBSA median), and white versus non-white (majority of tract population white/non-white). We use these in our models of residential choice.

Tables 5 and 6 show trends in the proportion of residential moves into these neighborhood types. Table 5 shows moderate increases in the national average share of gentrifier households moving into low-income central city and high-income central city tracts, most of which occurs from 2000 to 2010. Table 6 shows much more striking trends, with sharp increases in moves to nonwhite central city tracts for all households. This at least partly reflects an increase in the number of such tracts: the share of neighborhoods in our sample defined as nonwhite central city increased from $12.2 \%$ in 1990 to $17.4 \%$ in 2010 . The share of tracts defined as low-income central city increased more modestly from $21.8 \%$ to $22.1 \%$.

\section{Moves to the Central City}

\footnotetext{
${ }^{8}$ See Freeman (2005) and McKinnish, Walsh, and White (2010) for examples of studies that use these definitions.
} 
Our core aim is to examine whether falling violent crime rates in cities change the probability that high-income, college-educated, and white households choose homes in central cities, and also homes in lower-income and majority minority central city neighborhoods.

\subsection{Base Model}

To test whether drops in crime are attracting households with greater choices back into central cities, we estimate a linear probability model in which the dependent variable captures whether a mover household chooses the central city over the suburbs. Specifically, we estimate the following regression:

$$
\mathrm{Y}_{\mathrm{ict}}=\alpha+\beta \mathrm{CRIME}_{\mathrm{ct}-1}+\lambda_{1} \mathrm{H}_{\mathrm{ict}}+\lambda_{2} \mathrm{X}_{\mathrm{ct}}+\kappa_{\mathrm{c}}+\tau_{\mathrm{t}}+\varepsilon_{\mathrm{ict}}
$$

where $i$ indexes the household, $c$ the CBSA and $t$ the time period. $\mathrm{Y}_{\text {ict }}$ is a binary variable that takes value 1 if a household moves to the largest central city in the CBSA and value 0 if it moves elsewhere in the CBSA. ${ }^{9}$ The unit of analysis is mover households. CRIME ct-1 $_{\text {represents either }}$ violent crime per capita in that largest central city or homicides per capita in the city. Both are measured in the year before the move to reflect information movers had at the time they made their residential choice. Results are robust to using two- or three-year lags, suggesting that reverse causality is not driving our results.

$\mathrm{H}_{\mathrm{ict}}$ is a set of household characteristics that theory and empirical research suggest shape residential choices, including family type (married, single mother, single father, and other);

\footnotetext{
${ }^{9}$ While most CBSAs only have one principal city, we include here CBSAs that have multiple principal cities and define the central city as the biggest of those cities. Results are robust to estimating models for only the CBSAs with one principal city.
} 
presence of children under 18; household income; householder race/ethnicity; householder foreign born status; and householder education level.

$\mathrm{X}_{\mathrm{ct}}$ represents a set of central city characteristics that help capture other changes occurring that might be correlated with crime and that might also affect household moves. The full set of city characteristics includes median gross rent; the median value of owner occupied housing; median household income; share of households in poverty; share of households who are non-white; share of households who are foreign born; share of housing units built before 1940; and share of housing units built in the past 10 years. In our regression models, we log the city characteristics and crime variables to capture how percentage changes in these variables affect the probability of moving to the central city. Our main results are robust to including these variables as levels instead.

Finally, $\kappa_{\mathrm{c}}$ represents a set of CBSA fixed effects and $\tau_{\mathrm{t}}$ a set of year fixed effects. By including CBSA fixed effects, we control for fixed, unobserved attributes of metropolitan areas and the relative attractiveness of their cities. By including year fixed effects, we control for broad trends in preferences or unobserved demographics. We cluster standard errors at the CBSA level to account for the fact that household error terms may be correlated within CBSAs.

We stratify our sample to separately show results for high-income versus low-income households, college-educated households versus those without college degrees, and white versus non-white households. We formally test for significant differences between coefficients in the stratified models.

The key coefficient of interest is $\beta$. Because we include CBSA fixed effects, it is identified from variation in crime and patterns of residential moves within CBSAs over time. Thus, negative values are interpreted as evidence that falling crime in a city is associated with an 
increase in the probability that households of a particular type choose to move into that central city instead of its surrounding suburbs, as we hypothesize.

Table 7 presents the linear probability model results for our key crime variables. Each column is fully stratified by the stated gentrifier type. We do not report the results for household characteristics, but they yield some interesting, if expected, insights into other factors associated with moves to the central city. ${ }^{10}$ For all household types, having children in the household is associated with a lower probability of moving to the central city. For low-income, high-income, and white households a college degree is associated with a greater probability of moving to the central city, while for non-white households it is associated with a lower probability. Households with a head of household under 35 are more likely to choose homes in the central city across all household types. Interestingly, few of the city characteristics are correlated with prevalence of moves to the central city by non-gentrifier households, while more are correlated with moves by gentrifier households. This suggests that city trends are differentially associated with the residential choices of gentrifier and non-gentrifier households, which we control for here and in a more data-driven way below. While the coefficient signs generally make sense, these variables are measured contemporaneously with our outcome variables, due to data constraints, and thus we make no claims regarding causality.

As for our key coefficient of interest, we see that changes in violent crime are not associated with any change in the prevalence of moves into the central city by low-income, noncollege-educated, or non-white households. However, falling crime is strongly associated with increased probability that high-income, college-educated, and white households choose to settle in the central city. A similar pattern holds when homicides is the key variable. Moreover, Chow tests of the difference in coefficients reveal that these associations are significantly stronger for

\footnotetext{
${ }^{10}$ Full results are available from the authors upon request.
} 
high-income than low-income households, for college-educated than non-college-educated households, and for white than non-white households (though the last only when crime is measured as homicides). We find very similar results when we estimate these models on a sample of the 100 largest CBSAs for 2000 to 2010, when the movement of high-income and college-educated households to cities was strongest.

To provide a sense of the magnitude of these results, the coefficient on violent crime for high-income households is $-0.03 .{ }^{11}$ For a fall in violent crime from 1988 to 2008 of 18.2 percent (the mean decline from Table 3), this yields an increase in the probability that a high-income household moves to the central city of $-0.03 * \ln (0.818)=0.006$, or 0.6 percentage points. This is not unimportant, given that the observed increase in this probability in our sample is 3.7 percentage points, from 28.1 to 31.8 percent.

\subsection{Robustness to Other Trends: Double Selection Model}

The key to establishing causality is ruling out reverse causality and omitted variable bias. We address reverse causality by lagging crime, and our results are robust to lagging one, two, or three years. We control for omitted variables that vary across CBSAs but are fixed over time with CBSA fixed effects, and we control for omitted trends that are fixed across CBSAs with year effects. As for time-varying, omitted metropolitan area variables, we would ideally find an exogenous instrument for crime that 1) affects residential decisions only through its effect on crime, and 2) is sufficiently strong in predicting crime. We experimented with many instruments, including state prison admittances and releases (Cullen and Levitt 1999), lead exposure (Reyes 2007), and police grants (Evans and Owens 2007). However, these were all

\footnotetext{
${ }^{11}$ This means that a one percent decrease in violent crime increases the probability that a high-income household chooses a home in the central city instead of the suburbs by $-0.03 * \ln (0.99)=.0003$, or .03 percentage points.
} 
originally used with annual data, generally greater geographic detail, and with different outcomes of interest. None of them both satisfied the exclusion restriction and were sufficiently strong in our sample of three time periods and 244 CBSAs.

Instead, we address the threat of time varying omitted variables through the "double selection" method of Belloni, Chernozhukov, and Hansen (2014), a data-driven version of selection on observables. The key insight of this approach is that while researchers may have some ideas a priori of which variables should be included in their models as controls, and in what functional forms, this knowledge will be imperfect. They therefore propose a more systematic approach. The first step is to identify all the variables thought to be possibly correlated with either the outcome or the endogenous variable of interest and to create many higher-order interactions among these variables to flexibly capture other potential trends. Because including all of these as controls in the model is inefficient, they suggest running two separate LASSO (Least Absolute Shrinkage and Selection Operator) regressions, one with the outcome variable as the dependent variable and one with the endogenous variable of interest as the dependent variable, to select just those variables that are correlated with the dependent variables. The number of variables chosen is determined by the penalty term, and Belloni, Chernozhukov, and Hansen (2014) provide values that compromise between inclusivity and efficiency, which we use.

The next step is to estimate OLS regressions including the union of all variables selected by the two LASSO regressions. While only variables correlated with both the outcome and the endogenous variable will create bias if omitted, using the union instead of the intersection of the two sets ensures that variables only moderately correlated with one of the two variables are still included. 
To implement this method, we begin with all of the household characteristics from Table 4, central city characteristics from Table 1, and equivalent versions of CBSA characteristics. We create squares and all pairwise combinations of these characteristics. We modify the first step of the double selection in two ways. First, because we are interested in testing for differences in crime coefficients between gentrifier and non-gentrifier households, we also want to allow the variables associated with moves by gentrifier and non-gentrifier households to differ. We therefore stratify the sample by gentrifier type and run lasso regressions separately by gentrifier status. For example, when testing for differences between high- and low-income households, we stratify by income and run LASSO regressions separately for high- and low-income households, which selects variables correlated with either moves by high-income households or moves by low-income households. CBSA fixed effects are included so that the correlations are identified from variation within CBSAs over time. Many variables are selected, mostly involving interactions between household types and other household types, central city characteristics, and CBSA characteristics.

We also modify the way we find variables correlated with crime trends. Because this variation is at the CBSA-year level, we aggregate the sample from the household level to the CBSA-year level. For each of violent crime per capita and homicides per capita, we run LASSO regressions with crime as the dependent variable and central city variables, CBSA variables, and squares of and interactions between them as independent variables. CBSA fixed effects are again included so that the correlations are identified from variation within CBSAs over time.

Results from running the base models of Section 4.1 with controls from the double selection method are presented in Tables 8,9 , and 10 . Table 8 shows the results stratifying by high income status. The crime coefficients from Table 7 are reproduced in the "Standard 
controls" columns. The violent crime coefficients are 0 for low-income households and -0.03 for high-income households, the latter statistically significant at the 1 percent level. The row below indicates that Chow tests reveal that the low- and high-income coefficients are different from each other at the 1 percent level. The parsimonious model includes just the variables selected by the double selection method. In this model the coefficient for high-income households falls to 0.018 but remains significant at the 1 percent level. The difference between the low- and highincome coefficients remains significant at the 5 percent level. Finally, the column "Parsimonious model with standard controls" includes as controls both those used in Table 7 and those found by the double selection method. This conservative model thus includes both the variables we think are important a priori and those found within the data to be most correlated with the outcome or endogenous variable of interest. The coefficients remain about the same, and the coefficient for high-income households is still qualitatively and statistically more negative than that for low-income households, as in the standard model. Patterns are similar for these households when using homicides per capita as the crime variable.

Table 9 shows that for stratifications by college education, the double selection method halves the coefficient on violent crime, eroding the difference between college- and non-college households and rendering it statistically insignificant in our final specification. However, when crime is measured as homicides, the difference found in the standard models, while eroded, remains statistically significant. Finally, Table 10 shows that the small but statistically significant difference in homicide coefficients between white and non-white households becomes even smaller and not statistically significant when using the double selection method.

Additionally, we replicate this analysis for the sample of the 100 biggest CBSAs (where crime declines were greatest) from 2000 to 2010 (when gentrification trends were strongest) and 
find similar results. ${ }^{12}$ When using this more recent sample, the differences in crime coefficients between high- and low-income households are robust to double selection when using violent crime ${ }^{13}$ and homicides. Differences between college-educated and non-college-educated households and between white- and non-white households are slightly more robust to double selection in this more recent sample. Differences in the probability of choosing a city location by college education remain significant for both violent crime and homicides, and differences by white remain significant when homicides is the crime variable.

Overall, our results are robust to using this double selection method. Controlling for a rich set of additional variables found to be correlated with either the outcome variable or the crime variable, the differences in crime coefficients between high- and low-income households are eroded somewhat but remain statistically significant when using either violent crime or homicides as the measure of crime. The difference in responsiveness to crime between collegeeducated and non-college-educated households holds when crime is measured by homicides and also when crime is measured as all violent crimes for the 100 largest metropolitan areas from 2000 to 2010. Finally, results on responsiveness to crime between white and non-white households are only robust to double selection method for homicides in our most recent sample of the 100 largest metropolitan areas.

\section{Moves into Low-Income and Non-White Central City Neighborhoods}

So far we have focused on whether falling violent crime is associated with an increased likelihood that gentrifier households will choose central city neighborhoods instead of suburban

\footnotetext{
12 Results available from authors upon request.

${ }^{13}$ Results on violent crime are still statistically significant for high-income households and not statistically significant for low-income households, but the differences between these coefficients are only statistically significant at the 15 percent level.
} 
neighborhoods. We also want to learn whether declines in crime are shaping the types of central city neighborhoods that gentrifier households will consider. Specifically, we examine whether falling crime is increasing the probability that high-income, college-educated, and white households choose to settle in low-income or majority minority (non-white) central city neighborhoods when they move.

To do this, we run models identical to our base models from Section 4.1 but re-define $Y_{\text {ict }}$ from a binary variable to one of two different multinomial variables.

$Y_{i c t}^{\text {inc }}$ takes a value of 1 if a household moves to a low-income central city neighborhood, 2 if it moves to a high-income central city neighborhood, and 3 if it moves to the suburbs. $Y_{i c t}^{\text {eth }}$ takes values 1 if a household moves to a majority non-white central city neighborhood, 2 if it moves to a majority white central city neighborhood, and 3 if it moves to the suburbs. We then estimate the following multinomial logit models (McFadden, 1978) with the same control variables as in equation (1) above, stratifying by household type:

$$
\begin{aligned}
& Y_{i c t}^{i n c}=\alpha+\beta \text { CRIME }_{\mathrm{ct}-1}+\lambda_{1} \mathrm{H}_{\mathrm{ict}}+\lambda_{2} \mathrm{X}_{\mathrm{ct}}+\kappa_{\mathrm{c}}+\tau_{\mathrm{t}}+\varepsilon_{\mathrm{ict}} \\
& Y_{i c t}^{\text {eth }}=\alpha+\beta \mathrm{CRIME}_{\mathrm{ct}-1}+\lambda_{1} \mathrm{H}_{\mathrm{ict}}+\lambda_{2} \mathrm{X}_{\mathrm{ct}}+\kappa_{\mathrm{c}}+\tau_{\mathrm{t}}+\varepsilon_{\mathrm{ict}}
\end{aligned}
$$

Table 11 presents results from estimating equations (2) and (3) stratifying the sample by low-income vs. high-income households and reports Chow tests of differences between coefficients for low-income and high-income households. Panel A shows that falling violent crime and falling homicides are associated with an increase in the odds that a high-income household moves to a low-income central city neighborhood relative to the suburbs. Fitting with our hypothesis, this association between falling crime and moves to low-income, central city tracts is stronger for high-income households than for low-income households (which itself is not statistically significant) when either homicides or violent crime is used. 
Consider the results when using homicides as the measure of crime. The coefficient on moves to low-income central city tracts (instead of to the suburbs) for high-income households is -0.043 . To interpret the magnitude of this result, we consider the response to the mean change in homicides of -20.4 percent (from Table 3). This yields an increase in the relative odds of moving to a low-income central city tract instead of the suburbs of $1 \% .^{14}$

Panel B of Table 11 shows similar patterns: falling crime is associated with increased moves by high-income households to non-white central city neighborhoods but not moves by low-income households into those neighborhoods. Additionally, this difference in associations between high- and low-income households is economically and statistically significant, supporting our hypothesis of greater responsiveness of high-income households to falling central city crime. The coefficients are also generally larger: using similar calculations as those described above, the coefficient on homicides for high-income households yields a $3 \%$ increase in the relative odds of moving to a non-white central city tract instead of the suburbs in response to a 20.4 percent decline in homicides.

Table 12 presents multinomial logit results stratifying by households without and with a college degree. Panel A shows that the association between falling central city crime and moves to low-income central city neighborhoods is only stronger for college households than for noncollege households when violent crime is measured with homicides. However, Panel B shows that moves into non-white central city tracts are more associated with crime for college households when either definition of crime is used. Note that while coefficients for the models with homicides were not disclosed due to minor sample changes required to get models to converge, the indicators of significant differences accurately reflect whether there are significant

\footnotetext{
${ }^{14} \exp (-0.043 * \ln (.796))=1.01$, a $1 \%$ increase in the odds ratio from a base of 1.
} 
differences between the coefficients estimated in the sample without and with a college degree. We will disclose these results in full once final samples are determined after any revisions.

Table 13 presents results when stratifying by non-white and white households. Panels A and B show that falling crime is not associated with moves by white households into either lowincome central city or non-white central city neighborhoods. Moreover, there are no consistently significant differences in moves between white households and non-white households. The results thus provide little evidence that falling central city crime is shaping the residential choices of white households.

Overall, the multinomial logit results suggest that when violent crime in the central city and in particular the homicide rate - falls, higher income and college-educated households are

more likely to settle in all types of central city neighborhoods, including low-income and largely minority central city neighborhoods. Moreover, we see no similar associations for low-income households or for households without college degrees. Thus, falling central city violent crime and homicides appear to be causing a shift in the composition of households moving to urban neighborhoods, potentially contributing to gentrification.

\section{Conclusion}

This research provides support for the notion that reductions in central city violent crime and homicides are inviting high-income and college-educated households to move into central cities, and more specifically to low-income and largely minority central city neighborhoods. Furthermore, these relationships are substantively and significantly stronger for high-income households compared to low-income households and for college-educated households compared to those without college degrees. Our results hold in a full sample of 244 large CBSAs from 
1990 to 2010 and in a smaller sample of the 100 largest CBSAs from 2000 to 2010 . They are robust to including a rich set of time-varying household, central city, and CBSA characteristics selected in a data-driven way. And they are consistent with a simple monocentric model in which violent crime falls in the city center and high-income and college-educated households either have different sensitivities to violent crime or different information about trends in violent crime.

Our results do not suggest that crime is the only factor driving the shift in location choices. Recent work by Couture and Handbury (2016) and Baum-Snow and Hartley (2016) finds evidence that the growing preferences of young, college-educated households for urban amenities is driving much of the increase in moves by this group into areas very close to the CBD from 2000 to 2010. However, we do not believe this shift in preferences fully explains our results, and in fact reduced crime might contribute to shifting preferences as people are better able to enjoy urban amenities when violence levels fall. Our focus on a much broader geographic area (the entire biggest city in the CBSA) and time span (1990 to 2010) further allays concerns that our results are driven completely by recent trends very near CBDs.

Taken together, our results suggest that the dramatic decrease in violent crime experienced by central cities over the past three decades could be contributing to changes in the composition of movers to central city neighborhoods, including those that are low-income and predominantly minority, with implications for gentrification, neighborhood change, and economic integration. 


\section{Acknowledgements}

This work was supported by the Annie E. Casey Foundation and the Open Society Foundations. 


\section{References}

Baum-Snow, N. and D. Hartley (2015). Gentrification and Changes in the Spatial Structure of Labor Demand. Working Paper.

Bayoh, I., Irwin, E.G., and T. Haab (2006). Determinants of Residential Location Choice: How Important Are Local Public Goods in Attracting Homeowners to Central City Locations? Journal of Regional Science 46(1):97-120.

Belloni, A., Chernozhukov, V, and C. Hansen (2014). High-Dimensional Methods and Inference on Structural and Treatment Effects. Journal of Economic Perspectives 28(2):29-50.

Brueckner, J. and S. Rosenthal (2009). Gentrification and Neighborhood Housing Cycles: Will America's Future Downtowns Be Rich? The Review of Economics and Statistics 91(4):725-743.

Brueckner, J., Thisse, J.-F., and Y. Zenou (1999). Why is Central Paris Rich and Downtown Detroit Poor? An Amenity-Based Theory, European Economic Review 43:91-107.

Couture, V. and J. Handbury (2016). Urban Revival in America, 2000 to 2010. Working Paper.

Cullen, J. and S. Levitt (1999). Crime, Urban Flight, and the Consequences for Cities. The Review of Economics and Statistics 81(2):159-169.

Edlund, L., Machado, C. and M. M. Sviatschi (2015). Bright Minds, Big Rent: Gentrification and the Rising Returns to Skill. NBER Working Paper 21729.

Ellen, I.G., Horn, K.M. and K. O'Regan (2013). Pathways to Integration: Examining changes in the prevalence of racially integrated neighborhoods. Cityscape 14(3):33-54.

Ellen, I.G. and K. O'Regan (2010). Crime and Urban Flight Revisited: The effect of the 1990s drop in crime on cities. Journal of Urban Economics 68:247-259.

Evans, W. and E. Owens (2007). COPS and Crime. Journal of Public Economics 91(1-2): 181201.

Frey, W. (1979). Central City White Flight: Racial and Nonracial Factors. American Sociological Review 44(3):425-448.

Freeman, L. (2005). Displacement of Succession? Residential Mobility in Gentrifying Neighborhoods. Urban Affairs Review 40(4):463-491.

Freeman, L. and F. Braconi (2004). Gentrification and Displacement: New York City in the 1990s. Journal of the American Planning Association 70(1):39-52. 
Glaeser, E. and J. Gottlieb (2006). Urban Resurgence and the Consumer City. Urban Studies 43(8):1275-1299.

Glaeser, E., Kolko, J. and A. Saiz (2001). Consumer City. Journal of Economic Geography 1:2750.

Kirk, D. and J. Laub (2010). Neighborhood Change and Crime in the Modern Metropolis. Crime and Justice 39(1):441-502.

Kern, C. (1981). Upper-Income Renaissance in the City: Its Sources and Implications for the City's Future. Journal of Urban Economics 9:106-124.

Krysan, Maria (2002). Community Undesirability in Black and White: Examining Racial Residential Preferences through Community Perceptions. Social Problems 49(4):521543.

Kurlat, P. and J. Stroebel (2015). Testing for Information Asymmetries in Real Estate Markets. Review of Financial Studies 28(8):2429-2461.

McFadden, D. (1978). Modelling the Choice of Residential Location. Spatial Interaction Theory and Planning Models, Amsterdam: North Holland, 1978, pp. 75-96.

McKinnish, T., Walsh, R. and T. White (2010). Who Gentrifies Low-Income Neighborhoods? Journal of Urban Economics 67:180-193.

Morenoff, J.D. and R. J. Sampson (1997). Violent Crime and the Spatial Dynamics of Neighborhood Transition: Chicago, 1970-2990. Social Forces 76(1): 31-64.

Nechyba, T. and R. P. Strauss (1997). Community Choice and Local Public Services: A Discrete Choice Approach. Regional Science and Urban Economics 28:51-73.

O’Sullivan, A. (2005). Gentrification and Crime. Journal of Urban Economics 57:73-85.

Rainie, L., Zickuhr, K., Purcell, K., Madden, M., and J. Brenner (2012). The Rise of E-Reading Part 2: General Reading Habits of Americans. Pew Research Center. http://libraries.pewinternet.org/2012/04/04/part-2-the-general-reading-habits-ofamericans/

Reyes, J. W. (2007). Environmental Policy as Social Policy? The Impact of Childhood Lead Exposure on Crime. The B.E. Journal of Economic Analysis and Policy 7(1) article 51. 
Table 1 Central City Characteristics

\begin{tabular}{lrrr}
\hline & 1990 & 2000 & 2010 \\
\hline Total households & 84,175 & 90,864 & 94,130 \\
\hline Share minority & $27.9 \%$ & $35.3 \%$ & $40.4 \%$ \\
\hline Share foreign born & $5.9 \%$ & $8.5 \%$ & $10.2 \%$ \\
\hline Share college education or more & $21.8 \%$ & $24.8 \%$ & $27.4 \%$ \\
\hline Share households in poverty & $17.3 \%$ & $16.7 \%$ & $19.1 \%$ \\
\hline Share housing units built before 1940 & $22.2 \%$ & $19.1 \%$ & $19.2 \%$ \\
\hline Share housing units built in last 10 years & $16.5 \%$ & $12.3 \%$ & $10.0 \%$ \\
\hline Median gross rent, 2010 dollars & 698 & 718 & 795 \\
\hline $\begin{array}{l}\text { Median value of owner-occupied housing, 2010 } \\
\text { dollars }\end{array}$ & 127,589 & 141,340 & 184,839 \\
\hline Median household income, 2010 dollars & 44,084 & 46,384 & 44,478 \\
\hline $\mathrm{N}$ & 244 & 244 & 244 \\
\hline
\end{tabular}


Table 2 Sample Trends in Central City Crime Rates

\begin{tabular}{lrrr}
\hline & \multicolumn{3}{c}{ Central City Crime } \\
Year & 1988 & 1998 & 2008 \\
\hline Violent crime per 1,000 population & 13.5 & 11.5 & 8.9 \\
\hline Homicides per 1,000 population & .18 & .14 & .12 \\
\hline $\mathrm{N}$ & 244 & 244 & 244 \\
\hline
\end{tabular}

Note: Mean across all central cities in sample, weighted by 2010 central city population. 
Table 3 Variation in 1988 to 2008 Crime Changes Across Central Cities

\begin{tabular}{|r|r|r|}
\hline & $\begin{array}{l}\text { Percent change } \\
\text { declines, violent } \\
\text { crime per capita }\end{array}$ & $\begin{array}{l}\text { Percent change } \\
\text { declines, } \\
\text { homicides per } \\
\text { capita }\end{array}$ \\
\hline $10 \%$ & $-73.8 \%$ & $-75.7 \%$ \\
\hline $25 \%$ & $-56.9 \%$ & $-59.5 \%$ \\
\hline $50 \%$ & $-25.9 \%$ & $-38.4 \%$ \\
\hline $75 \%$ & $7.9 \%$ & $0.6 \%$ \\
\hline $90 \%$ & $43.9 \%$ & $40.2 \%$ \\
\hline Mean & $-18.2 \%$ & $-20.4 \%$ \\
\hline Std. Dev. & $50.5 \%$ & $72 \%$ \\
\hline $\mathrm{N}$ & 244 & 244 \\
\hline
\end{tabular}

Note: Weighted by 2010 central city population. 
Table 4 Household Characteristics

\begin{tabular}{lrrrr}
\hline & $\begin{array}{r}\text { All } \\
\text { households }\end{array}$ & $\begin{array}{r}\text { High- } \\
\text { income } \\
\text { households }\end{array}$ & $\begin{array}{r}\text { College } \\
\text { households }\end{array}$ & $\begin{array}{r}\text { White } \\
\text { households }\end{array}$ \\
\hline Married & $40.6 \%$ & $60.8 \%$ & $45.1 \%$ & $42.5 \%$ \\
\hline Male headed & $5.0 \%$ & $4.9 \%$ & $2.5 \%$ & $4.0 \%$ \\
\hline Female headed & $15.1 \%$ & $7.1 \%$ & $6.0 \%$ & $11.0 \%$ \\
\hline Presence of children under 18 & $40.5 \%$ & $42.6 \%$ & $29.3 \%$ & $35.2 \%$ \\
\hline Linguistically isolated & $6.3 \%$ & $3.2 \%$ & $4.0 \%$ & $1.8 \%$ \\
\hline Household income, 2010 & & & & \\
dollars & 24,300 & N/A & 40,100 & 26,900 \\
\hline Householder white & $69.3 \%$ & $78.1 \%$ & $78.2 \%$ & N/A \\
\hline Householder black & $12.3 \%$ & $7.1 \%$ & $6.3 \%$ & N/A \\
\hline Householder Hispanic & $10.6 \%$ & $7.5 \%$ & $4.9 \%$ & N/A \\
\hline Householder other non-white & $7.8 \%$ & $7.3 \%$ & $10.6 \%$ & N/A \\
\hline Less than high school & & & & \\
education & $17.3 \%$ & $8.2 \%$ & N/A & $12.1 \%$ \\
\hline High school education & $23.1 \%$ & $18.4 \%$ & N/A & $23.2 \%$ \\
\hline Some college education & $31.2 \%$ & $30.2 \%$ & N/A & $32.6 \%$ \\
\hline College education or more & $28.4 \%$ & $43.2 \%$ & N/A & $32.1 \%$ \\
\hline Foreign born & $14.8 \%$ & $12.8 \%$ & $16.0 \%$ & $5.5 \%$ \\
\hline Employed & $75.8 \%$ & $88.6 \%$ & $87.2 \%$ & $78.7 \%$ \\
\hline Age less than 35 & $52.5 \%$ & $46 \%$ & $54 \%$ & $52 \%$ \\
\hline Age 35 to 65 & $41.0 \%$ & $50.3 \%$ & $42.1 \%$ & $40.6 \%$ \\
\hline Age over 65 & $6.5 \%$ & $3.7 \%$ & $3.9 \%$ & $7.4 \%$ \\
\hline N & 454,000 & $1,624,000$ & $1,180,000$ & $2,878,000$ \\
\hline
\end{tabular}


Table 5 Moves by Neighborhood Income

\begin{tabular}{lrrr}
\hline & 1990 & 2000 & 2010 \\
\hline All Households & & & \\
Central city low-income & 24 & 24 & 25.7 \\
Central city high-income & 10.4 & 9.7 & 11 \\
Suburban & 65.6 & 66.3 & 63.2 \\
\hline High Income Households & & & \\
Central city low-income & 13.9 & 14 & 15.9 \\
Central city high-income & 14.2 & 13.1 & 15.9 \\
Suburban & 72 & 72.9 & 68.2 \\
\hline College-Educated Households & & & \\
Central city low-income & 19.1 & 18.6 & 21.7 \\
Central city high-income & 15.9 & 15.4 & 17.2 \\
Suburban & 64.9 & 66.1 & 61.1 \\
\hline White Households & & & \\
Central city low-income & 18.4 & 16.8 & 19.4 \\
Central city high-income & 11.3 & 10.7 & 12.4 \\
Suburban & 70.4 & 72.6 & 68.2 \\
\hline N &
\end{tabular}

Note: Sample sizes of households by year not disclosed until final sample is determined based on requested revisions. 
Table 6 Moves by Neighborhood Ethnicity

\begin{tabular}{lrrr}
\hline & 1990 & 2000 & 2010 \\
\hline All Households & & & \\
Central city non-white & 10.3 & 13.6 & 17.1 \\
Central city white & 24.1 & 20 & 19.7 \\
Suburban & 65.6 & 66.3 & 63.2 \\
\hline High Income Households & & & \\
Central city non-white & 5.3 & 7.9 & 11.2 \\
Central city white & 22.8 & 19.3 & 20.7 \\
Suburban & 72 & 72.9 & 68.2 \\
\hline College-Educated Households & & & \\
Central city non-white & 5.2 & 7.8 & 12.2 \\
Central city white & 29.9 & 26.2 & 26.7 \\
Suburban & 64.9 & 66.1 & 61.1 \\
\hline White Households & & & \\
Central city non-white & 4 & 4.5 & 7.9 \\
Central city white & 25.6 & 22.9 & 23.8 \\
Suburban & 70.4 & 72.6 & 68.2 \\
\hline
\end{tabular}

Note: Sample sizes of households by year not disclosed until final sample is determined based on requested revisions. 
Table 7: Linear Probability Models, Probability of Moving to Central City vs. Suburbs

\begin{tabular}{|l|r|r|r|r|r|r|}
\hline \multicolumn{7}{|c|}{ Table 7 Panel A: Violent crime } \\
\hline & $\begin{array}{r}\text { Low- } \\
\text { Income }\end{array}$ & $\begin{array}{r}\text { High- } \\
\text { Income }\end{array}$ & $\begin{array}{r}\text { Non- } \\
\text { College }\end{array}$ & College & $\begin{array}{r}\text { Non- } \\
\text { White }\end{array}$ & White \\
\hline $\begin{array}{l}\text { Violent crime per capita, } \\
\text { ln }\end{array}$ & 0.000 & $-0.030^{* * *}$ & -0.002 & $-0.027 * * *$ & -0.007 & $-0.015^{* *}$ \\
\hline & $(0.010)$ & $(0.010)$ & $(0.006)$ & $(0.007)$ & $(0.013)$ & $(0.007)$ \\
\hline $\begin{array}{l}\text { Chow test of significant } \\
\text { difference between } \\
\text { stratified samples }\end{array}$ & & & & & \\
\hline \multicolumn{7}{|c|}{ Table 7 Panel B: Homicides } \\
\hline
\end{tabular}


Table 8: Double Selection Models, Low-Income and High-Income Households

\begin{tabular}{|c|c|c|c|c|c|c|}
\hline & \multicolumn{2}{|c|}{ Standard controls } & \multicolumn{2}{|c|}{ Parsimonious model } & \multicolumn{2}{|c|}{$\begin{array}{l}\text { Parsimonious model with } \\
\text { standard controls }\end{array}$} \\
\hline & \multicolumn{2}{|c|}{ Move to central city } & \multicolumn{2}{|c|}{ Move to central city } & \multicolumn{2}{|c|}{ Move to central city } \\
\hline \multicolumn{7}{|c|}{ Table 8, Panel A: Violent Crime } \\
\hline & $\begin{array}{l}\text { Low- } \\
\text { income }\end{array}$ & $\begin{array}{l}\text { High- } \\
\text { income }\end{array}$ & $\begin{array}{l}\text { Low- } \\
\text { income }\end{array}$ & $\begin{array}{l}\text { High- } \\
\text { income }\end{array}$ & $\begin{array}{l}\text { Low- } \\
\text { income }\end{array}$ & $\begin{array}{l}\text { High- } \\
\text { income }\end{array}$ \\
\hline $\begin{array}{l}\text { Violent crime } \\
\text { per capita, ln }\end{array}$ & 0.000 & $-0.030 * * *$ & -0.010 & $-0.018 * * *$ & 0.000 & $-0.015 * * *$ \\
\hline & $(0.010)$ & $(0.010)$ & $(0.010)$ & $(0.010)$ & $(0.010)$ & $(0.010)$ \\
\hline $\begin{array}{l}\text { Chow test of } \\
\text { significant } \\
\text { difference }\end{array}$ & & $* * *$ & & $* *$ & & $* * *$ \\
\hline \multicolumn{7}{|c|}{ Table 8, Panel B: Homicides } \\
\hline & $\begin{array}{l}\text { Low- } \\
\text { income }\end{array}$ & $\begin{array}{l}\text { High- } \\
\text { income }\end{array}$ & $\begin{array}{l}\text { Low- } \\
\text { income }\end{array}$ & $\begin{array}{l}\text { High- } \\
\text { income }\end{array}$ & $\begin{array}{l}\text { Low- } \\
\text { income }\end{array}$ & $\begin{array}{l}\text { High- } \\
\text { income }\end{array}$ \\
\hline \multirow[t]{2}{*}{$\begin{array}{l}\text { Homicides per } \\
\text { capita, ln }\end{array}$} & 0.000 & $-0.010 * *$ & 0.000 & $-0.008 * * *$ & 0.001 & $-0.006 * *$ \\
\hline & 0.000 & 0.000 & 0.000 & 0.000 & $(0.002)$ & $(0.003)$ \\
\hline $\begin{array}{l}\text { Chow test of } \\
\text { significant } \\
\text { difference }\end{array}$ & & $* * *$ & & $* * *$ & & **** \\
\hline Observations & $2,530,000$ & $1,624,000$ & $2,530,000$ & $1,624,000$ & $2,530,000$ & $1,624,000$ \\
\hline \multicolumn{7}{|c|}{ Cluster-robust standard errors } \\
\hline \multicolumn{7}{|c|}{$* * * \mathrm{p}<0.01, * * \mathrm{p}<0.05, * \mathrm{p}<0.1$} \\
\hline CBSA fixed eff & included & & & & & \\
\hline
\end{tabular}


Table 9: Double Selection Models, College-Educated and Non-College-Educated Households

\begin{tabular}{|c|c|c|c|c|c|c|}
\hline & \multicolumn{2}{|c|}{ Standard controls } & \multicolumn{2}{|c|}{ Parsimonious model } & \multicolumn{2}{|c|}{$\begin{array}{l}\text { Parsimonious model with } \\
\text { standard controls }\end{array}$} \\
\hline & \multicolumn{2}{|c|}{ Move to central city } & \multicolumn{2}{|c|}{ Move to central city } & \multicolumn{2}{|c|}{ Move to central city } \\
\hline \multicolumn{7}{|c|}{ Table 9, Panel A: Violent Crime } \\
\hline & $\begin{array}{l}\text { Non- } \\
\text { college }\end{array}$ & College & $\begin{array}{l}\text { Non- } \\
\text { college }\end{array}$ & College & $\begin{array}{l}\text { Non- } \\
\text { college }\end{array}$ & College \\
\hline $\begin{array}{l}\text { Violent crime } \\
\text { per capita, ln }\end{array}$ & -0.002 & $-0.027 * * *$ & -0.008 & $-0.015^{* *}$ & -0.002 & -0.011 \\
\hline & $(0.006)$ & $(0.007)$ & $(0.005)$ & $(0.007)$ & $(0.005)$ & $(0.007)$ \\
\hline $\begin{array}{l}\text { Chow test of } \\
\text { significant } \\
\text { difference }\end{array}$ & & $* * *$ & & & & \\
\hline \multicolumn{7}{|c|}{ Table 9, Panel B: Homicides } \\
\hline & $\begin{array}{l}\text { Non- } \\
\text { college }\end{array}$ & College & $\begin{array}{l}\text { Non- } \\
\text { college }\end{array}$ & College & $\begin{array}{l}\text { Non- } \\
\text { college }\end{array}$ & College \\
\hline $\begin{array}{l}\text { Homicides per } \\
\text { capita, ln }\end{array}$ & -0.001 & $-0.011 * * *$ & 0.000 & $-0.008 * *$ & 0.000 & $-0.007 * *$ \\
\hline & $(0.003)$ & $(0.004)$ & $(0.002)$ & $(0.003)$ & $(0.002)$ & $(0.003)$ \\
\hline $\begin{array}{l}\text { Chow test of } \\
\text { significant } \\
\text { difference }\end{array}$ & & $* * *$ & & $* *$ & & $* *$ \\
\hline Observations & $2,974,000$ & $1,180,000$ & $2,974,000$ & $1,180,000$ & $2,974,000$ & $1,180,000$ \\
\hline \multicolumn{7}{|c|}{ Cluster-robust standard errors } \\
\hline \multicolumn{7}{|c|}{$* * * \mathrm{p}<0.01, * * \mathrm{p}<0.05, * \mathrm{p}<0.1$} \\
\hline CBSA fixed ef & ts included & & & & & \\
\hline
\end{tabular}


Table 10: Double Selection Models, White and Non-White Households

\begin{tabular}{|c|c|c|c|c|c|c|}
\hline & \multicolumn{2}{|c|}{ Standard controls } & \multicolumn{2}{|c|}{ Parsimonious model } & \multicolumn{2}{|c|}{$\begin{array}{l}\text { Parsimonious model with } \\
\text { standard controls }\end{array}$} \\
\hline & \multicolumn{2}{|c|}{ Move to central city } & \multicolumn{2}{|c|}{ Move to central city } & \multicolumn{2}{|c|}{ Move to central city } \\
\hline \multicolumn{7}{|c|}{ Table 10, Panel A: Violent Crime } \\
\hline & Non-white & White & Non-white & White & Non-white & White \\
\hline $\begin{array}{l}\text { Violent crime } \\
\text { per capita, ln }\end{array}$ & -0.007 & $-0.015 * *$ & -0.013 & $-0.011^{*}$ & -0.004 & -0.005 \\
\hline & $(0.013)$ & $(0.007)$ & $(0.011)$ & $(0.006)$ & $(0.009)$ & $(0.006)$ \\
\hline $\begin{array}{l}\text { Chow test of } \\
\text { significant } \\
\text { difference }\end{array}$ & & & & & & \\
\hline \multicolumn{7}{|c|}{ Table 10, Panel B: Homicides } \\
\hline & Non-white & White & Non-white & White & Non-white & White \\
\hline $\begin{array}{l}\text { Homicides per } \\
\text { capita, ln }\end{array}$ & 0.005 & $-0.006^{*}$ & 0.001 & $-0.005^{*}$ & 0.003 & -0.003 \\
\hline & $(0.006)$ & $(0.003)$ & $(0.005)$ & $(0.003)$ & $(0.005)$ & $(0.002)$ \\
\hline $\begin{array}{l}\text { Chow test of } \\
\text { significant } \\
\text { difference }\end{array}$ & & $* *$ & & & & \\
\hline Observations & $1,276,000$ & $2,878,000$ & $1,276,000$ & $2,878,000$ & $1,276,000$ & $2,878,000$ \\
\hline \multicolumn{7}{|c|}{ Cluster-robust standard errors } \\
\hline \multicolumn{7}{|c|}{$* * * \mathrm{p}<0.01, * * \mathrm{p}<0.05, * \mathrm{p}<0.1$} \\
\hline CBSA fixed eff & ts included & & & & & \\
\hline
\end{tabular}


Table 11: Multinomial Logit Models, Moves by Low-Income and High-Income Households

\begin{tabular}{|c|c|c|c|c|c|c|}
\hline \multicolumn{7}{|c|}{ Table 11, Panel A: Moves to central city low-income neighborhoods } \\
\hline & \multicolumn{3}{|c|}{ Low-income households } & \multicolumn{3}{|c|}{ High-income households } \\
\hline & $\begin{array}{r}\text { Move to } \\
\text { low-income } \\
\mathrm{CC} \\
\end{array}$ & 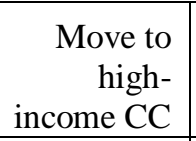 & $\begin{array}{r}\text { Move to } \\
\text { suburbs } \\
\text { (reference) } \\
\end{array}$ & $\begin{array}{r}\text { Move to } \\
\text { low-income } \\
\mathrm{CC} \\
\end{array}$ & $\begin{array}{r}\text { Move to } \\
\text { high- } \\
\text { income CC } \\
\end{array}$ & $\begin{array}{r}\text { Move to } \\
\text { suburbs } \\
\text { (reference) } \\
\end{array}$ \\
\hline $\begin{array}{l}\text { Violent crime per capita, } \\
\text { ln }\end{array}$ & 0.025 & $-0.099 * * *$ & & -0.073 & $-0.209 * * *$ & \\
\hline $\begin{array}{l}\text { Chow test of significant } \\
\text { difference }\end{array}$ & & & & $* * *$ & $* * *$ & \\
\hline Homicides per capita, ln & 0.015 & $-0.048 * *$ & & $-0.043 * *$ & $-0.087 * * *$ & \\
\hline $\begin{array}{l}\text { Chow test of significant } \\
\text { difference }\end{array}$ & & & & $* * *$ & $* *$ & \\
\hline \multicolumn{7}{|c|}{ Table 11, Panel B: Moves to central city non-white neighborhoods } \\
\hline & \multicolumn{3}{|c|}{ Low-income households } & \multicolumn{3}{|c|}{ High-income households } \\
\hline & $\begin{array}{r}\text { Move to } \\
\text { non-white } \\
\text { CC } \\
\end{array}$ & $\begin{array}{r}\text { Move to } \\
\text { white CC }\end{array}$ & $\begin{array}{r}\text { Move to } \\
\text { suburbs } \\
\text { (reference) } \\
\end{array}$ & $\begin{array}{r}\text { Move to } \\
\text { non-white } \\
\mathrm{CC} \\
\end{array}$ & $\begin{array}{r}\text { Move to } \\
\text { white CC }\end{array}$ & $\begin{array}{r}\text { Move to } \\
\text { suburbs } \\
\text { (reference) }\end{array}$ \\
\hline $\begin{array}{l}\text { Violent crime per capita, } \\
\text { ln }\end{array}$ & -0.029 & $0.089 * *$ & & $-0.166^{*}$ & $-0.107 * *$ & \\
\hline $\begin{array}{l}\text { Chow test of significant } \\
\text { difference }\end{array}$ & & & & $* * *$ & $* * *$ & \\
\hline Homicides per capita, ln & -0.029 & 0.021 & & $-0.135 * * *$ & $-0.051 * *$ & \\
\hline $\begin{array}{l}\text { Chow test of significant } \\
\text { difference }\end{array}$ & & & & $* * *$ & $* * *$ & \\
\hline Observations & $2,530,000$ & & & $1,624,000$ & & \\
\hline \multicolumn{7}{|c|}{ Cluster-robust standard errors } \\
\hline \multicolumn{7}{|c|}{$* * * \mathrm{p}<0.01, * * \mathrm{p}<0.05, * \mathrm{p}<0.1$} \\
\hline CBSA fixed effects incluc & & & & & & \\
\hline
\end{tabular}


Table 12: Multinomial Logit Models, Moves by Non-College and College Households

\begin{tabular}{|c|c|c|c|c|c|c|}
\hline \multicolumn{7}{|c|}{ Table 12, Panel A: Moves to central city low-income neighborhoods } \\
\hline & \multicolumn{3}{|c|}{ Non-college households } & \multicolumn{3}{|c|}{ College households } \\
\hline & $\begin{array}{r}\text { Move to } \\
\text { low-income } \\
\text { CC }\end{array}$ & $\begin{array}{r}\text { Move to } \\
\text { high- } \\
\text { income CC }\end{array}$ & $\begin{array}{r}\text { Move to } \\
\text { suburbs } \\
\text { (reference) }\end{array}$ & $\begin{array}{r}\text { Move to } \\
\text { low-income } \\
\mathrm{CC}\end{array}$ & $\begin{array}{r}\text { Move to } \\
\text { high- } \\
\text { income CC }\end{array}$ & $\begin{array}{r}\text { Move to } \\
\text { suburbs } \\
\text { (reference) }\end{array}$ \\
\hline $\begin{array}{l}\text { Violent crime per capita, } \\
\text { ln }\end{array}$ & 0.011 & $-0.0962 * * *$ & & -0.028 & $-0.192 * * *$ & \\
\hline $\begin{array}{l}\text { Chow test of significant } \\
\text { difference }\end{array}$ & & & & & $*$ & \\
\hline Homicides per capita, ln & 0.008 & $-0.039 * *$ & & -0.03 & $-0.106 * * *$ & \\
\hline $\begin{array}{l}\text { Chow test of significant } \\
\text { difference }\end{array}$ & & & & $* *$ & $* * *$ & \\
\hline \multicolumn{7}{|c|}{ Table 12, Panel B: Moves to central city non-white neighborhoods } \\
\hline & \multicolumn{3}{|c|}{ Non-college households } & \multicolumn{3}{|c|}{ College households } \\
\hline & $\begin{array}{r}\text { Move to } \\
\text { non-white } \\
\text { CC }\end{array}$ & $\begin{array}{r}\text { Move to } \\
\text { white CC }\end{array}$ & $\begin{array}{r}\text { Move to } \\
\text { suburbs } \\
\text { (reference) }\end{array}$ & $\begin{array}{r}\text { Move to } \\
\text { non-white } \\
\text { CC }\end{array}$ & $\begin{array}{r}\text { Move to } \\
\text { white CC }\end{array}$ & $\begin{array}{r}\text { Move to } \\
\text { suburbs } \\
\text { (reference) }\end{array}$ \\
\hline $\begin{array}{l}\text { Violent crime per capita, } \\
\ln \end{array}$ & -0.035 & $0.087 * *$ & & $-0.166 * *$ & $-0.070 *$ & \\
\hline $\begin{array}{l}\text { Chow test of significant } \\
\text { difference }\end{array}$ & & & & $* *$ & $* * *$ & \\
\hline & & & & & & \\
\hline Homicides per capita, ln & \begin{tabular}{|l|} 
Not \\
disclosed
\end{tabular} & $\begin{array}{l}\text { Not } \\
\text { disclosed }\end{array}$ & & $\begin{array}{l}\text { Not } \\
\text { disclosed }\end{array}$ & $\begin{array}{l}\text { Not } \\
\text { disclosed }\end{array}$ & \\
\hline $\begin{array}{l}\text { Chow test of significant } \\
\text { difference }\end{array}$ & & & & $* *$ & ** & \\
\hline Observations & $2,974,000$ & & & $1,180,000$ & & \\
\hline \multicolumn{7}{|c|}{ Cluster-robust standard errors } \\
\hline \multicolumn{7}{|c|}{$* * * \mathrm{p}<0.01, * * \mathrm{p}<0.05, * \mathrm{p}<0.1$} \\
\hline CBSA fixed effects incluc & & & & & & \\
\hline
\end{tabular}

Note: Coefficient estimates were not disclosed when the multinomial logit models would not converge with the standard sample. By dropping a handful of CBSAs with extremely few moves of these types, we were able to get these models to converge. The Chow test cells reflect results from these samples. However, the slight sample changes required to get convergence preclude disclosure of coefficients until a final sample is determined after final revisions. 
Table 13: Multinomial Logit Models, Moves by Non-White and White Households

\begin{tabular}{|c|c|c|c|c|c|c|}
\hline \multicolumn{7}{|c|}{ Table 13, Panel A: Moves to central city low-income neighborhoods } \\
\hline & \multicolumn{3}{|c|}{ Non-white households } & \multicolumn{3}{|c|}{ White households } \\
\hline & $\begin{array}{r}\text { Move to } \\
\text { low-income } \\
\mathrm{CC} \\
\end{array}$ & $\begin{array}{r}\text { Move to } \\
\text { high- } \\
\text { income CC }\end{array}$ & $\begin{array}{r}\text { Move to } \\
\text { suburbs } \\
\text { (reference) }\end{array}$ & $\begin{array}{r}\text { Move to } \\
\text { low-income } \\
\mathrm{CC} \\
\end{array}$ & $\begin{array}{r}\text { Move to } \\
\text { high- } \\
\text { income CC }\end{array}$ & $\begin{array}{r}\text { Move to } \\
\text { suburbs } \\
\text { (reference) }\end{array}$ \\
\hline $\begin{array}{l}\text { Violent crime per capita, } \\
\ln \end{array}$ & -0.064 & $-0.175 * * *$ & & 0.01 & $-0.166 * * *$ & \\
\hline $\begin{array}{l}\text { Chow test of significant } \\
\text { difference }\end{array}$ & & & & $*$ & & \\
\hline Homicides per capita, $\ln$ & 0.017 & -0.043 & & -0.008 & $-0.079 * * *$ & \\
\hline \multicolumn{7}{|l|}{$\begin{array}{l}\text { Chow test of significant } \\
\text { difference }\end{array}$} \\
\hline \multicolumn{7}{|c|}{ Table 13, Panel B: Moves to central city non-white neighborhoods } \\
\hline & \multicolumn{3}{|c|}{ Non-white households } & \multicolumn{3}{|c|}{ White households } \\
\hline & $\begin{array}{r}\text { Move to } \\
\text { non-white } \\
\mathrm{CC} \\
\end{array}$ & $\begin{array}{r}\text { Move to } \\
\text { white CC }\end{array}$ & $\begin{array}{r}\text { Move to } \\
\text { suburbs } \\
\text { (reference) }\end{array}$ & $\begin{array}{r}\text { Move to } \\
\text { non-white } \\
\mathrm{CC} \\
\end{array}$ & $\begin{array}{r}\text { Move to } \\
\text { white CC }\end{array}$ & $\begin{array}{r}\text { Move to } \\
\text { suburbs } \\
\text { (reference) }\end{array}$ \\
\hline $\begin{array}{l}\text { Violent crime per capita, } \\
\ln \end{array}$ & -0.07 & -0.025 & & -0.186 & -0.017 & \\
\hline \multicolumn{7}{|l|}{$\begin{array}{l}\text { Chow test of significant } \\
\text { difference }\end{array}$} \\
\hline Homicides per capita, $\ln$ & -0.006 & 0.02 & & -0.058 & -0.024 & \\
\hline \multicolumn{7}{|l|}{$\begin{array}{l}\text { Chow test of significant } \\
\text { difference }\end{array}$} \\
\hline Observations & \multicolumn{3}{|l|}{$1,276,000$} & \multicolumn{3}{|l|}{$2,878,000$} \\
\hline \multicolumn{7}{|c|}{ Cluster-robust standard errors } \\
\hline \multicolumn{7}{|c|}{$* * * \mathrm{p}<0.01, * * \mathrm{p}<0.05, * \mathrm{p}<0.1$} \\
\hline CBSA fixed effects inclu & & & & & & \\
\hline
\end{tabular}

